\title{
Forkhead Box Protein N3
}

National Cancer Institute

\section{Source}

National Cancer Institute. Forkhead Box Protein N3. NCI Thesaurus. Code C18055.

Forkhead box protein N3 (490 aa, $\sim 54 \mathrm{kDa}$ ) is encoded by the human FOXN3 gene. This protein is involved in cell cycle regulation, embryonic development and transcription. 